\title{
The Singing Wolf Meets His Kin Abroad. Web-based databases of the Estonian Folklore Archives
}

\author{
Risto Järv \\ Estonian Literary Museum, Estonian Folklore Archives \\ risto@folklore.ee
}

\begin{abstract}
Estonian folklorists have created several databases for on-site use and also a couple of dozen web-based databases to facilitate research and increase the accessibility of archival material. The article gives a survey of four web-based databases managed by the researchers of the Estonian Folklore Archives: runic songs, place-lore, children's games and folktales. On the one hand, these databases are tools that can be used for research purposes and for preparing text publications; on the other hand, they can be used by a wide range of interested parties. As the databases have been prepared over a long period of time, and some of them are based on on-site databases, the principles on which they have been created differ to some extent.
\end{abstract}

KEYWORDS

Databases; folksong; place-lore; children's games; folktales

\section{RESUM}

Els folkloristes estonians han creat diverses bases de dades en local, a més d'un parell de desenes de bases de dades en linia per facilitar la tasca de la recerca i incrementar l'accessibilitat al material d'arxiu. Aquest treball proporciona una visió general de quatre bases de dades en línia gestionades pels investigadors dels Arxius de Folklore d'Estònia: cançons rúniques, el folklore local, jocs infantils i rondalles. D'una banda, aquestes bases de dades es poden fer servir per a finalitats de recerca i per preparar textos per ser publicats; de l'altra, poden ser d'interès per a molta altra gent no especialitzada. Tenint en compte que s'han preparat durant un llarg període de temps $i$ que algunes s'han elaborat a partir d'una base de dades en local, els principis que regeixen el funcionament poden ser diferents.

PARAules Clau

Bases de dades; cançons; folklore local; jocs infantils; rondalles

REBUT: 3O/II/2OI6 | ACCEPTAT: I2/I2/2OI6

Estudis de Literatura Oral Popular, núm. 5, 20I6, 29-44 | DOI: 10.I7345/elop20I629-44 ISSN: 20I4-7996 | http://revistes.urv.cat/index.php/elop 
It WAS IN 2 OII that I first came across the Catalan database of folktales RondCat. At the time I was working on an article for the Enzyklopädie des Märchens on the tale type The Wolf is Caught Because of His Singing (ATU IOO). In this internationally well-known tale type, a dog invites the wolf to a feast, where the wolf sings in spite of the dog's objections. Most of the versions do not end well for the poor wolf (Järv 2OI2). According to my computer files, I started from the copies suggested by the encyclopedia team and ended up finding the tales included in Joan Amades' collection (tales 262, 282, 285). When searching the web for the titles, I came across the database RondCat, which I checked for more detailed background information on the versions of the tale type.

Although the texts themselves could not be accessed by anonymous users (luckily, I already had the texts in my possession), I was able to acquire additional information and realised that databases had several potential uses. I discussed these with my colleagues at the Estonian Folklore Archives when developing the solutions for the web-based database of Estonian folktales. Before that, our database, which was created in I999, had been accessible on site for our own workgroup and the archive visitors. This year it has finally been made available on the web. The following is comparision and discussion of this database, with the three others managed by the Estonian Folklore Archives. ${ }^{\mathrm{I}}$

The Estonian Folklore Archives was founded in 1927 to create one central home for Estonian folklore materials. While large-scale folklore collecting had already started by the second half of the igth century and resulted in copious folklore collections (see e.g. Västrik 2OIO: 4-5; Järv, Sarv 20I4: 49-52), the aim to consolidate material from the whole nation mirrored similar attempts made in the neighbouring countries of Finland and Latvia, as well as Lithuania (WolfKnuts 2OOI: IO-I2; Västrik 2OIO: 9-IO.) As Diana Berg points out in her research on the founding of the Estonian Folklore Archives, the first decision to create an Estonian folklore archive at the University of Tartu was made in May I926. Its first clause read as follows, "To acknowledge that Dr. Hurt's collections and all other Estonian folklore collections need to be housed in one place" (Berg 2002: 19). The primary aim of this step was "to make them fully accessible to scholarship" (Berg 2002: I7; cf. Loorits I936: 34-35).

After the archives had been founded, folklore-related material collected by other institutions and researchers was also stored there. The archives were part

I. This research was supported by the Estonian Ministry of Education and Research (IUT 22-4; Scientific Collections of Estonian Research Programme), and by the European Union through the European Regional Development Fund (Centre of Excellence in Estonian Studies). 
of the Estonian National Museum, until it was restructured by the Soviet Regime in I940, when the folklore collections were moved to the newly-formed Estonian Literary Museum. Together with other archives and departments, the Estonian Folklore Archives belongs to this research institution to this day.

Although during the Soviet period, in the second half of the 2oth century, separate folklore collections were created at the University of Tartu and the Institute of Language and Literature in Tallinn; since Estonia regained its independence, these collections have been transferred to the Folklore Archives (see Järv, Sarv 20I4: 53-54).

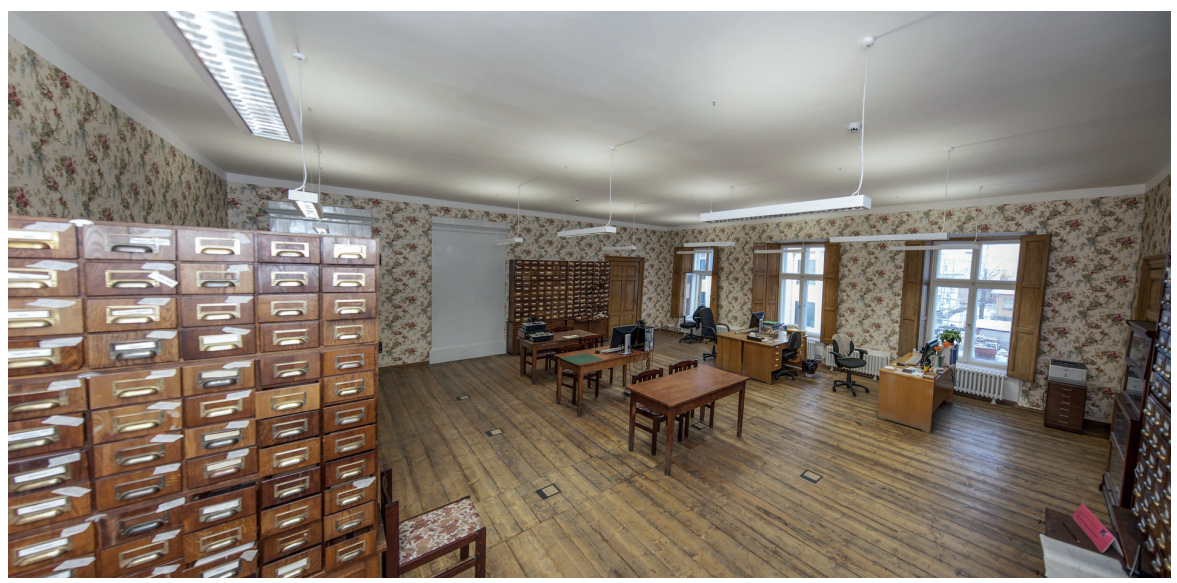

The Archives Reading Room after renovation works in 20I3. Photo: Alar Madisson. ERA, DF 33139.

In the system of the Scientific Collections of Estonian Research, the National Collection of Estonian Folklore is one of ten national collections and is managed by the Folklore Archives. All in all, the Archives, which today houses I.5 million manuscript pages and 62,000 photos, contains four collections - the manuscript collection, the photograph collection, the collection of sound recordings, and the film and video collection (for more details see Järv 20I3: 294-295).

Material stored in the folklore archives are used by both the general public and folklorists. Estonian folklorists work in a wide range of different institutions, which has resulted in multi-faceted research. Most of the Estonian folklorists work in three different institutions in Tartu: the Estonian Folkore Archives at the Estonian Literary Museum, the Department of Folkloristics of the same institution, and the Department of Estonian and Comparative Folklore at the University of Tartu. There is also a single, yet influential, scholar in the field who is employed at the Institute of Humanities of Tallinn University.

These different institutions, particularly the Department of Folkloristics and the Estonian Folklore Archives, have created various databases from the material stored at the Archives. The web page <http://www.folklore.ee/ebaas/> of the Estonian folklorists' server lists more than a couple of dozen databases, the earliest of which were started in 1997 (cf. Kõiva, Vesik 2004). Most of the databases are genre databases or databases concerned with broader topics, such as runic songs 
(folksongs), folk belief narratives, folktales, riddles, 'peripheral' riddle forms (conundrums, droodles, abbreviation formulae etc.), sayings, folk calendars, mummings, internet jokes, ethnobotany, etc. In some cases these serve as supplements to the academic publications of folklorists, and so are compilations that have been integrated with published material (e.g. the multifaceted database of Estonian riddles compiled by Arvo Krikmann <http://www.folklore.ee/ moistatused/> that serves as a supplement to the academic edition of Estonian riddles) (EM I, EM II).

Almost all texts in the databases are in Estonian, and a few have Englishlanguage interfaces. At the moment, the only database that has been fully translated into English is the database of Estonian droodles available at <http:// www.folklore.ee/Droodles/> (for a survey article, see Voolaid 2003).

The reason there is such a large number of databases is partly because of the principles of funding: first and foremost, small teams were given project-based support for this type of work. (Actually, the databases are even more numerous; in addition to the web-based databases, several more are accessible only on site.) On the one hand, all of this has had a remarkably positive side: each team compiling a database has been led by a specialist (or several specialists) in the particular field, who were using the material in their own active research and who were able to assess the needs of possible users relatively accurately. The leader of a team compiling and maintaining a database is usually assisted by a work group consisting of two or three people, who help to develop the database. This is important for users as well, for it makes it possible to easily find the material required by the researcher or other interested parties. As was pointed out by Oskar Loorits, the first director of Estonian Folklore Archives, from the very beginning the institution has not just been regarded as responsible for collecting and organising the material, but also for carrying out other important activities such as organizing, publishing and researching folklore (Loorits I932: 47-49; Berg 200I: 25).

On the other hand, the work is divided among many small teams, which makes it difficult to obtain a comprehensive survey of the folklore material that has been collected as a whole. As the old volumes of manuscripts have been studied and the contents entered into databases by each team separately, the condition of the manuscripts has been affected and it has been more time-consuming all in all. As one item of folkore can be categorised under several different genres, some of the material has been entered more than once - that is, it can be found in the databases of different genres - while a large part of the folklore collections is still waiting to be classified. In addition, the projects usually only partly funded, which is why some of their planned aims were not achieved. Thus the genrebased nature of the databases of Estonian folklore that has been predominant until recently appears to have had its weaknesses as well as its strengths.

The researchers of the Estonian Folkore Archives itself manage four of the webbased genre-centred and thematic databases - runic songs, place-lore, children's games and folktales - which will be briefly described below. In addition, there are several earlier on-site genre-based and/or thematic databases. (The fifth webbased database - runic song melody database - is being prepared.) 


\section{The database of Estonian runic songs}

\section{http://www.folklore.ee/regilaul/andmebaas/}

The runic song (runosong, regilaul in Estonian) shares the archaic folksong tradition of several Finnic peoples and is regarded as the most impressive part of Estonian folklore. When the initiator of large-scale folklore collecting, the clergyman Jakob Hurt, launched the all-encompassing project to record Estonian oral heritage in I876 entitled Monumentae Estoniae antiquae (see e. g. Jaago 2005: 53-55), he was planning to publish all runic songs in volumes and classified by the parish they were recorded in (the parish as a historical administrative unit still retains its significance in regionally locating earlier folklore material; there are IOI parishes in Estonia altogether). Unfortunately, this major work, which intends to produce commented academic editions, has been proceeding rather slowly, and by 2014 only Volume II (VK XI), containing runic songs from the Kodavere parish in Northern Tartumaa, had been published. The aim of creating the database of runic songs that was started in 2003 was to make all Estonian runic song texts easily accessible for both researchers and the public. This initiative was to be parallel to the well-commented and well-organized parish-based publications.

The first part of the project was conducted in cooperation with the Finnish Literature Society. Texts of runic songs found in the earlier typewritten copies were scanned and OCRed, missing texts typed up hand, and the texts collated to the original manuscripts; in addition to the exact letter by letter version, a slightly edited version of the texts was created to remove the peculiarities of spelling and orthography of the different collectors, and make the texts more easily readable and searchable. The database has various search options in addition to the possibility of searching by its archival reference. There are separate search fields for the parish where the recording was made; the collector; the time of the recording; the class, function, type and genre. As the typewritten copies of the songtexts are clearly structured, with all the metadata, xml-files can be created automatically from the original and proofread/edited versions separately. The database that was made available on the web in 2010 follows the model of the Finnish database and has similar contents and structure. The original aim has been to create parallel databases that offer similar search opportunities (see the Finnish Literature Society's SKVR-database <http://skvr.fi > which provides a web search of the runos of the Kalevala, and the discussion in Harvilahti 20I3).

Each song can be viewed in its initial version (the details of the written text are as close to the original as possible; both the historical spelling of the time of the recording and the individual idiosyncratic features of the collectors have been retained) and in an edited version (the lines follow today's orthographic rules proceeding from how they may have sounded on the basis of the written recording; dialectal peculiarities and the collector's own phrasing have been retained). This version makes it easier for a non-specialist to use the database. The existence of the partly edited version has its shortcomings, however, for a lay user may get the mistaken impression that extracts from the database can be published just as they are (e.g., an edition on a region would need no additional editing or competent commentary). Thus, although the database is easy to use and can also serve as a song book, folklorists will still have to educate the users further 
on the specific nature of archival material. The search results (or a selection) are downloadable in text-format (metadata and song text) and as xml.

In late 20I6, the database of Estonian runic songs contained 83,547 texts, approximately two-thirds of all the texts of runic songs that have found their way into the Archives since the start of folklore collecting. The database has an Englishlanguage interface <http://www.folklore.ee/regilaul/andmebaas/?ln=en>.

At present, the texts are being systematized: that is to say, the different forms of type name are being standardized because the indexes from different time periods have been using different type names to refer to the same type.

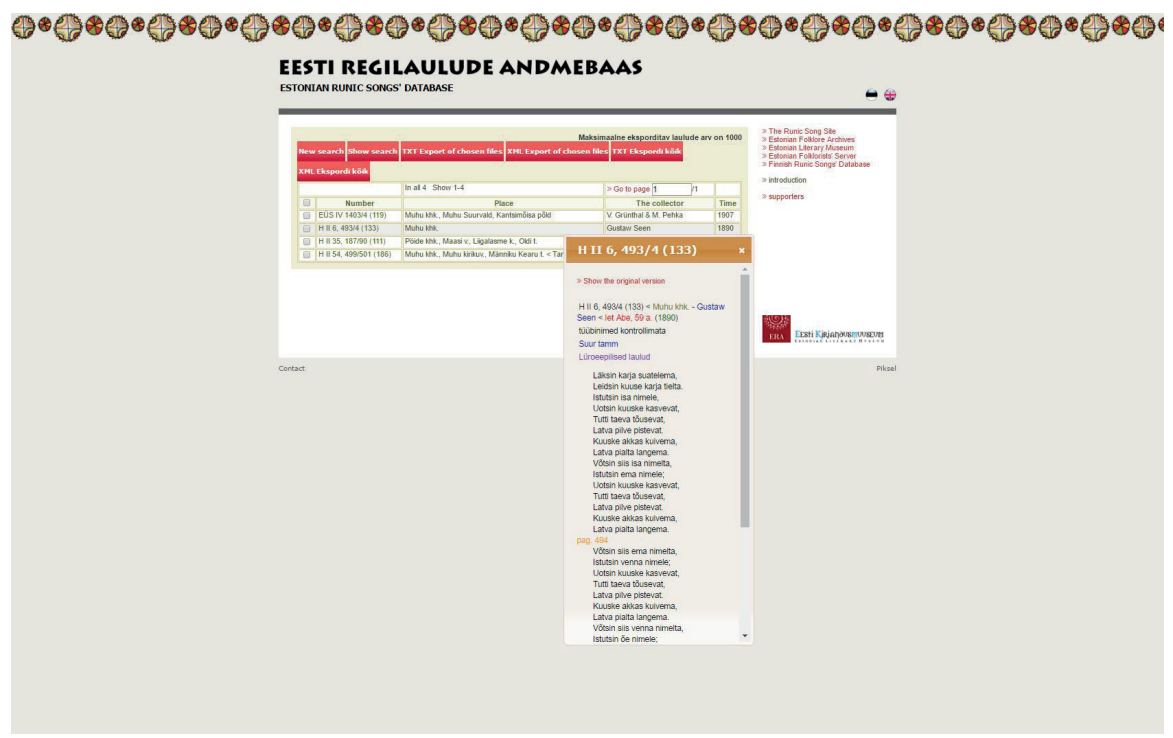

A search in the song type Big Oak (restricted to Saaremaa County). An edited version of a text from I890; recorded in the Muhu parish, the collector Gustav Seen has recorded Iet Abe's performance. H II 6, 493/4 (I33).

\section{The database of place-lore}

\section{http://galerii.kirmus.ee/koobas/ ("Koobas")}

Estonian place-lore has been a field of interest for researchers (folklorists, archeologists, geographers, etc.) as well as the general public (local enthusiasts, local history compilers, tourists etc.) for more than two decades. The term place-lore is an umbrella term that could be defined as folklore focusing on place(name)s usually transmitted in prose and involving (local) legends as well as beliefs, descriptions of customs, historical lore, memoirs, etc., related to places (Remmel 2OI4: 3I). As in the case of runic songs, the intention was to make all the information on Estonian place-lore available in print as well as a database. As well as preparing publications on (old) parishes (e.g. the lore from Urvaste Parish in South Estonia; Valper 20IO), the research team has also prepared publications in collaboration with the locations in question - either municipalities (e.g. Rae municipality; Remmel 2OII), regions (e.g. Järva County in Central Estonia; 
Remmel 2004), or institutions such as national parks, which may encompass several administrative units. The publications of the place-lore work group include comprehensive commentaries that explain the location-specific features of the place-lore and its historical and social context.

The database was initially created for on-site use in 1998. Standard office database software was used. The web-based database was created from it in 2012. The name of the database, "Koobas", means "cave" in Estonian.

In late 2016 the database contained 28,560 entries. It contains more Estonian locations from the specific regions of study of the researchers in the work group (the Juuru and Jüri parishes in Northern Estonia, Otepää parish in South Estonia, the various parishes within the borders of the Matsalu and Vilsandi national parks in West Estonia and Saaremaa island) for as many archival records as possible related to these areas have been entered into the database.

The place-lore database is also included as a component in the cluster database of archeological and folklore-related information on places on the server of the Estonian Heritage Board (http://register.muinas.ee) where it can be used by archaeologists and scholars studying sacred sites, as well as by the Heritage Board itself.

Side by side with earlier archival manuscripts, the materials collected during recent field work are an important part of the place-lore database, the aim of which is not only to digitise and publish earlier records but also to supplement these with fieldwork materials representing the current period. Because the results of recent field work are subject to personal data protection restrictions, as well as restrictions due to the preparatory work of research projects and the vulnerability of some landscape objects to treasure-hunting "detectorist" archeology, much of the database is not accessible to the public. At present, approximately an eighth of the entries can be accessed by users without logging in, but the number is bound to grow significantly in the coming years.

The database entries have been structured as follows:

- $\quad$ archival reference (full reference and its separate subcomponents: the folklore collection, volume, the first and the last pages of the archival piece, and the number of the piece), year(s) of collection, performer(s) and collector(s) with their dates of birth and additional information;

- the metadata of the material (the type of the object; the characters involved, the relevant genres, very short description ("type") of the text);

- the folklore site or sites referred to in the text (the name of the object, the region and the parish in the igth-century administrative system, today's region, municipality and village; GPS-coordinates);

- the text itself;

- $\quad$ additional data (data on publication and access restrictions);

- list of work processes connected with the entry (date of digitisation, date of checking);

- reference to the link in the Kivike repository. 
The acronym Kivike stands for "Kirjandusmuuseumi virtuaalne kelder" ('the virtual cellar of the Literary Museum') and denotes the Literary Museum's central digital archival system. Created in 2OII, it combines the possibilities of a repository, archival information system, database, and research environment (cf. Järv, Sarv 20I3: 56-59; Kulasalu 20I5). It can be used for the safe storage of the digitisations of the manuscripts (as well as photo, audio and video materials) and it can be datasearched by users. If the manuscripts are digitised (at the moment, by no means all of them are), users can access the respective digitised page of the archival volume from the genre database and observe it alongside the computerformatted texts. Likewise, materials collected by the same folklore collector can also be accessed. Also the database of runic songs will be provided with a similar functional connection with Kivike.

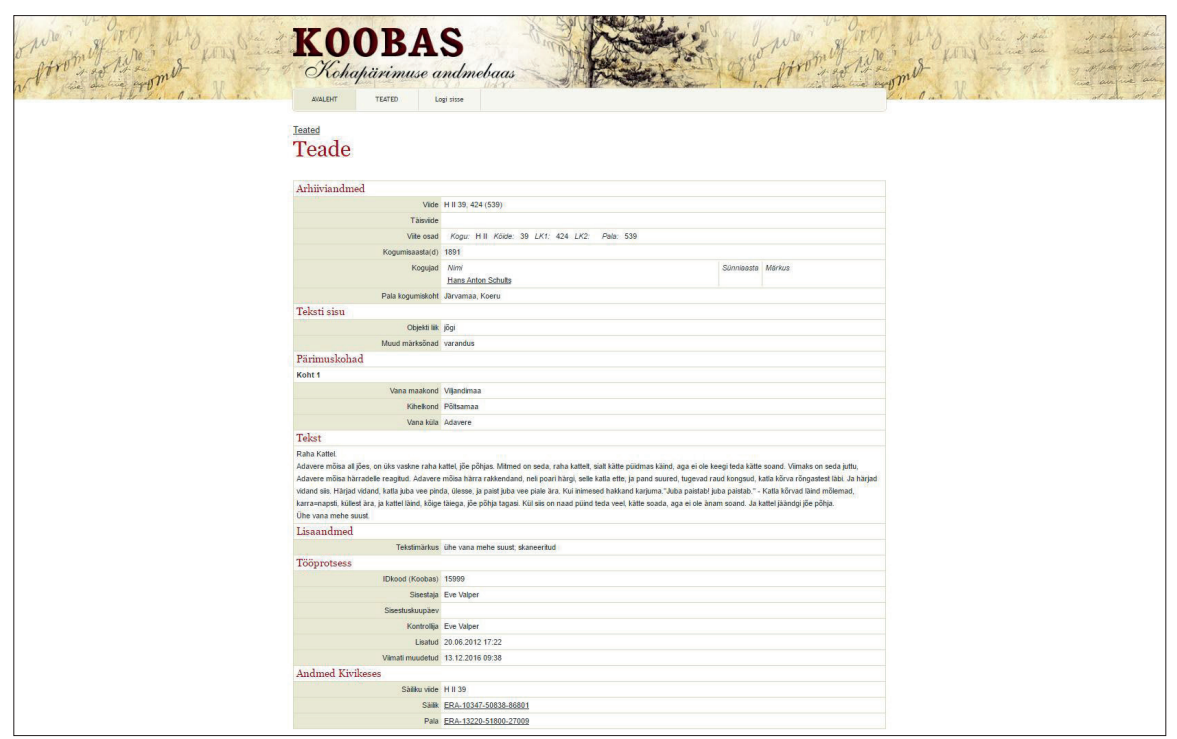

An entry from the place-lore database: a legend of a kettle full of money in the river close to Adavere manor in Järva County; recorded by Hans Anton Schultz (I89I). H II 39, 424 (539). At the bottom, there are references to the digitised page of the original manuscript in the Kivike repository as well as to the respective archival piece.

\title{
3. The database of games
}

\author{
http://www.folklore.ee/ukauka/
}

\section{("Old and new games in the Folklore Archives")}

The database of games, the Folklore Archives' third database to have become accessible on the Internet, was created in 20I4. Just as other databases have been created to supplement or prepare for other publications, the database of children's games developed from the 2013 web-based publication of children's games "Old and new games in the Folklore Archives: I,OoI children's games from the year I935" (http://www.folklore.ee/ukauka/arhiiv/IooI) (Hiiemäe et alii 20I3). The 
publication was prepared for a campaign to collect children's games launched by the Archives in the same year. Although the databases of runic songs and placelore had been commissioned and technically set up by a software company, in this case the open source ready-made platform Omeka was used (http://omeka. org/, the platform that was created specifically for displaying library, museum and archive collections on the Internet). Since we were among the first users of the platform in Estonia, the enthusiastic employees of the Estonian Folklore Archives also created an Estonian-language Omeka interface while preparing the publication.

After the publication had been completed and the material from the collecting campaign had arrived, the Estonian Folklore Archives' work group on contemporary children's games decided to supplement the earlier collection with material collected in 2013. Indeed, most of the materials about children's games came from specific collecting campaigns and there are these that the steadily growing database is being built on: the campaign of children's games from I934-I935; the campaigns of children's lore of 1992 and 2007; and the campaign of children's games of 2013. These clusters of materials also provide a certain overview of the transformations that have been occurring in the field in the course of time. The material from the intermediate period, the Soviet years, was collected in I944-I98I by several pupils separately. Thus, it has yet to be determined whether there is enough material to justify inclusion in the database.

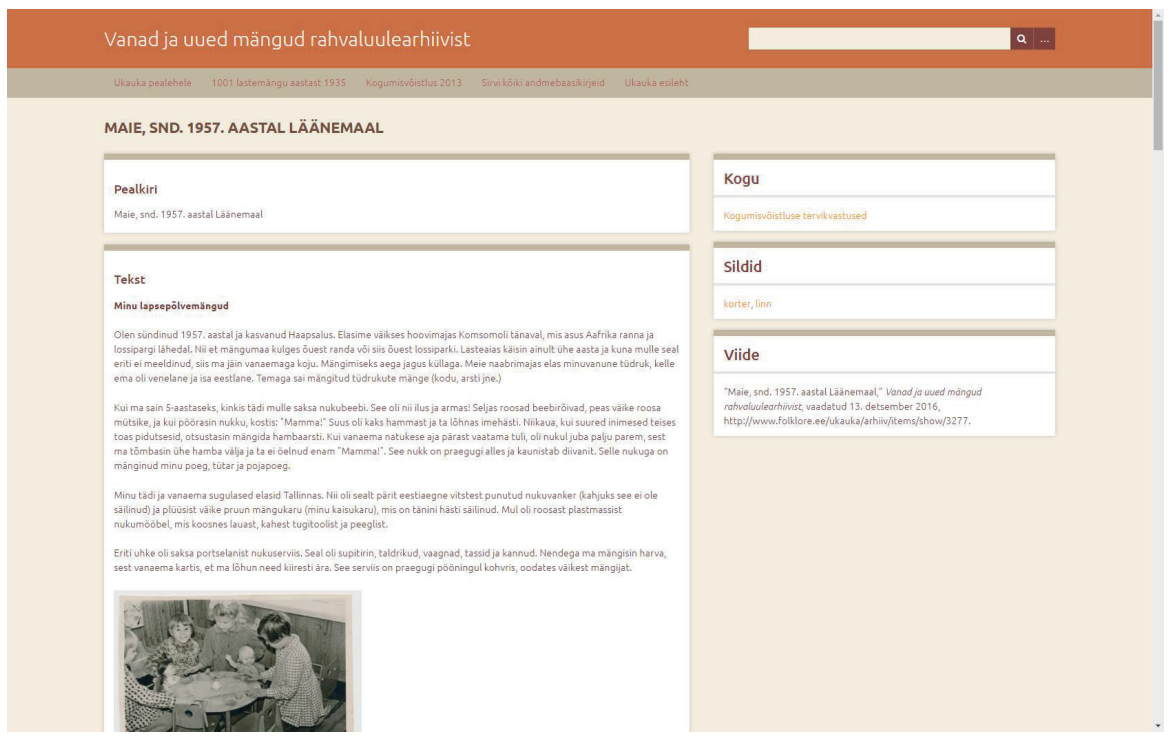

The most recent part of the Omeka-based database of children's games consists of descriptions of games collected in the contemporary period. A description of children's games in Läänemaa County (20I3). EFA I I68. 
The database of Estonian games provides an overview of the popular repertoire of games and contains both new and old, familiar and lesser-known games. Besides game descriptions, the database contains descriptions of playing situations and childhood memories connected with playing games. In addition, the database contains the different ways the games start (e.g dipping rhymes, counting-out rhymes). The contemporary descriptions of games have been represented in context, and include the time and place, and the age, gender and number of players, etc. The database is searchable by the name or the kind of the game or the activity it involves (for example, imitating, turning round on the spot, changing places). The texts are accompanied by the names of the regions in which the games were collected and the data on the collectors. There are links to the full list of the games collected in a particular region or by a particular collector. Each entry or Omeka item has also been marked with tags at different levels (the region, the kind of game and the activities, etc.) and structured in different colours.

In late 20I6, the database contained 2,077 descriptions of games and childhood memories, some of these accompanied by photos, figures and children's drawings. Like the database of runic songs, this database is fully accessible to the public.

\section{The database of folktales}

\section{http://www.folklore.ee/muinasjutt/andmebaas/}

As pointed out above, the database of folktales was created in I999, yet reached the internet only in 20I6. The initial database was devised by the University of Tartu and the Estonian Folklore Archives as a fairly simple tool, at least to start with. The folktales work group intended to compile and publish an academic anthology of fairy tale types (tale of magic; EMj 2009, EMj 2OI4) from the folktales stored in the archives that would cover all Estonian folktale types. However, the project soon expanded and preparation began on a database of Estonian folktales, which contained a bibliography, research work on folktales, and other compilations of published folktales (for detail, see EMj 2009: 583-588).

During this period the database was accessible to the researchers on site, as the first priority was to enter as many texts as possible in order to prepare publications and publish academic papers.

When the folktale project was planned in I999, it seemed expedient to start work right away. For this reason no database system was commissioned from an external source, but the team members immediately set about making the texts accessible using the simplest solution: a word processor. However, a systematic database of the texts' background data clearly needed to be created, containing the archival references, the names of the performers and the recorders, the places and dates when the texts were collected as well as the types of folktale. All these parameters have been marked on the texts as data fields. In the course of practical work, some additions were subsequently made to the list of data fields. Soon the work group expanded its digitising activities from folktales to other types of folktale. 
After the lengthy period during which the folktale database was on-site, the decision was taken to develop a web database. In the initial stages (2OI4-20I5), the folktale work group consulted similar databases created by researchers in various countries (for example, the database of Dutch folktales Nederlandse Volksverhalenbank, the Catalan database RondCat, the Portugese database of legends, the Icelandic database of legends Sagnagrunnur, etc.). For a while we were contemplating using an interface as similar as possible to the Dutch database, as the Dutch researchers had also adopted an Omeka-based solution in 2013 and were using standard Dublin Core metadata fields to facilitate the international exchange of data (see also Meder 20IO: I4-I5, Meder et alii 20I6: 83-84). In the end, this plan was abandoned, as we wished to integrate the database of folktales with the Literary Museum's central repository Kivike. We also decided that, unlike our Dutch colleagues (e.g. Meder 20IO: 7) we were not going to include transformed version of folktales (e. g. their occurrences as jokes in the database, although we have also collected this material, see e.g. Järv 2008: II8-I2O).

From among the databases of the Estonian Folkore Archives, in its revised format the web database resembles the one of place-lore the most. It allows contributors to insert new entries in text form, there is a multi-level access limitation system for users who are logged in and those who are not, and it can be synchronised with the database of the Literary Museum's digital archival system Kivike. Some fast search options by type, storyteller and recorder have been added to the main search function. The database has the option of complex type search, which was developed because of the needs of a work group that was engaged in systematising typology and preparing publications.

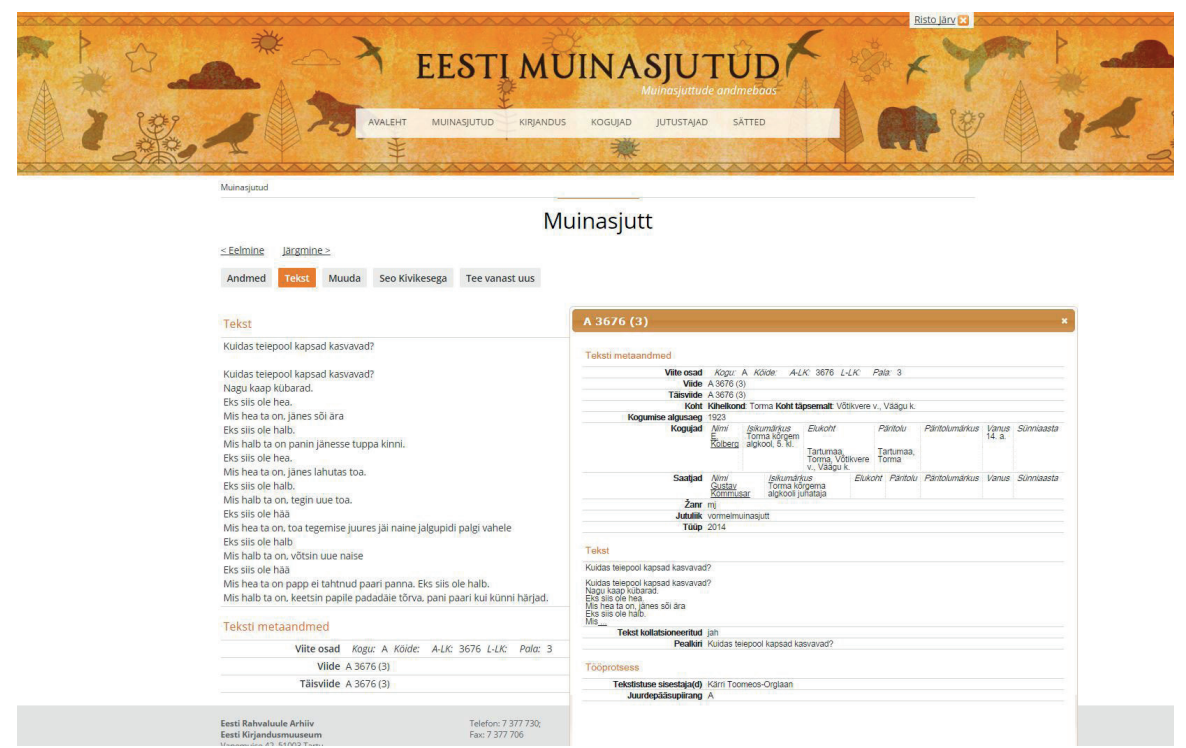

A cumulative tale "How are your cabbages growing?" (ATU 20I4) from Walter Anderson's collection of schoolchildren's lore. (I923). A 3676 (3). (Editorial view when logged in as a member of the folktale workgroup.) 
The database consists of the same three main categories that have been used in other databases of the Estonian Folklore Archives: tales (the text, the archival reference, details of the recording, date of the recording); collectors (with all relevant data); storytellers (with all relevant data). As in all folktale studies it is important to detect links with versions that have appeared in print, a fourth part has been constructed: a literature database (data on publications and the tales in them as well as any links with the originals stored in the archives, cf. Catalan database BiblioFolk: Oriol 2005: 342-343). Thus, all four parts are interconnected and any changes made in one part will automatically be reflected in the others.

In late 20I6, when data was first transferred to the web database, the onsite database contained I2,00o texts. To start with, only checked metadata and checked texts were gradually made available online but then completely new texts were experimentally added. In the future the aim is to enter new texts directly into the online database and not the on-site database.

Eventually, this database will also contain links to the scanned original materials, thus making handwritten originals accessible to the members of the work group and external researchers. The computerised versions of manuscript texts in the database enables users, for example, to translate them using machine translation so that they can be accessed by speakers of other languages. As yet, the database is a preliminary version and several new developments are going to be implemented in the coming years.

\section{Conclusion}

Estonian folklorists have created a couple of dozen web-based databases, four of which were devised by the researchers of the Estonian Folklore Archives of the Estonian Literary Museum. They can be used by professional researchers for research purposes and for preparing text publications and also by a wide range of interested parties.

Each database has been constructed with different functions in mind, depending on the needs of each work group.

\begin{tabular}{lccccc} 
& $\begin{array}{c}\text { Previous } \\
\text { on-site } \\
\text { database }\end{array}$ & $\begin{array}{c}\text { Ready- } \\
\text { made } \\
\text { software } \\
\text { solution }\end{array}$ & $\begin{array}{c}\text { Additional } \\
\text { functions } \\
\text { upon } \\
\text { logging in }\end{array}$ & $\begin{array}{c}\text { Continuous } \\
\text { addition of } \\
\text { contemporary } \\
\text { material }\end{array}$ & $\begin{array}{c}\text { Links } \\
\text { with the } \\
\text { Kivike file } \\
\text { repository }\end{array}$ \\
$\begin{array}{l}\text { Runic songs } \\
\text { (2010) }\end{array}$ & $\mathrm{X}$ & $\mathrm{X}$ & $\mathrm{X}$ & $\mathrm{X}$ & $(\mathrm{X})$ \\
$\begin{array}{l}\text { Place-lore } \\
(2012)\end{array}$ & $\mathrm{X}$ & & $\mathrm{X}$ & $\mathrm{X}$ \\
$\begin{array}{l}\text { Games } \\
\text { (2014) }\end{array}$ & $\mathrm{X}$ & & $\mathrm{X}$ & & $\mathrm{X}$ \\
$\begin{array}{l}\text { Folktales } \\
\text { (2016) }\end{array}$ & $\mathrm{X}$ & & & & \\
\hline
\end{tabular}


In 20I6, the work group on ethnomusicology started work on the fifth, runic song melody database, an adaptation of an older, on-site database.

The metadata of the databases that have come from different origins needs some standardisation today, and this need has become more pressing with the addition of each new database. As thematic databases appear to be a wellestablished and useful tool for researchers it seems expedient that they should be developed, but certain data needs to be standardised. This was vividly shown by the experience of transferring data from different databases to the Kivike repository. More than 400,000 entries were transferred to Kivike in 20I3, and the non-standardised state of the metadata meant that entries from different sources ended up being transferred on multiple occasions. The confusion was considerable.

Once this standarisation has been done, it is to be hoped that Estonian folk songs, folktales, the games today's grown-ups used to play in their childhood and even recently recorded place-lore can be conveniently accessed from the rest of the world, so that anybody interested in the Estonian version of the tale of the wolf who was caught because of his singing will be able to consult it with no more than a few clicks of the mouse. 


\section{References}

ATU = UTHER, Hans-Jörg (2004): The Types of International Folktales. A Classification and Bibliography. Based on the System of Antti Aarne and Stith Thompson. Part I: Animal Tales, Tales of Magic, Religious Tales, and Realistic Tales, with an Introduction. Folklore Fellows' Communications 284. Helsinki: Suomalainen Tiedeakatemia.

BERG, Diana (2002): "Eesti Rahvaluule Arhiivi saamislugu". [The story of founding the Estonian Folklore Archives]. In Mall HıımäE; Kanni LABi (eds.): Kogumisest uurimiseni. ArtikleidEesti Rahvaluule Arhiivi 75. aastapäevaks. [From collecting to studying. Articles on the 75th anniversary of the Estonian Folklore Archives]. Eesti Rahvaluule Arhiivi toimetused 20. Tartu: Eesti Kirjandusmuuseum, p. 9-28.

EM I = Eesti mõistatused I [Estonian Riddles], I-I350 = Aenigmata Estonica I, I-I350. Anne Hussar; Arvo KrikMAnN; Rein SaUKas; Piret Voolaid (comp.), Arvo KRIKMANN; Rein SAUKAS (eds.). Monumenta Estoniae antiquae IV: I. Tartu: Eesti Keele Sihtasutus 200I.

EM II = Eesti mõistatused II [Estonian Riddles II], I35I-2800 = Aenigmata Estonica II, I35I-280o. Anne Hussar; Arvo Krikmann; Rein Saukas; Piret Voolaid (comp.), Arvo KriKMANN; Rein SAUKAS (eds.). Monumenta Estoniae antiquae IV: 2. Tartu: Eesti Keele Sihtasutus 2002.

EMj 2009 = Eesti muinasjutud I:I. Imemuinasjutud. [Estonian Folktales I:I. Fairy tales]. Comp. and ed. by Risto Järv; Mairi KAASIK; Kärri TOOMEOS-OrglaAN. (Monumenta Estoniae antiquae V: I:I). Tartu: EKM Teaduskirjastus.

EMj $20 \mathrm{O} 4$ = Eesti muinasjutud I:2. Imemuinasjutud. [Estonian Folktales I:2. Fairy tales]. Comp. by Risto JÄrv; Mairi KAASIK, Kärri TOOMEOS-OrglaAn, ed. by Inge ANNOM; Risto JÄRV; Mairi KAASIK; Kärri TOOMEOS-OrglaAN. (Monumenta Estoniae antiquae V: I:2) Tartu: EKM Teaduskirjastus.

Harvilaht, Lauri (20I3): “The SKVR Database of Ancient Poems of the Finnish People in Kalevala Meter and the Semantic Kaleva". Oral Tradition vol. 28, no. 2 (October 2OI3): 223-232. <http://journal.oraltradition.org/issues/28ii/ harvilahti $>$ [last access: November 20I6].

Hiıemäe, Mall; Risto Järv; Kaisa Kulasalu; Mari SARv; Kadri Tamm; Astrid TUISK (eds.) (2003): IOOI lastemängu aastast I935. [IOOI childrens games from the year I935]. <http://www.folklore.ee/ukauka/arhiiv/IOoI> [last access: November 20I6].

JAAGO, Tiiu (2005): "Jakob Hurt: The Birth of Estonain-language Folklore Research". In: Kristin KuUTMA; Tiiu JAAGO (eds.): Studies in Estonian Folkloristics and Ethnology. A Reader and Reflexive History. Tartu: Tartu University Press.

JÄRV, Risto (2008): "Punamütsike ja Punasokike. Muinasjutunaljadest". [Little Red Riding Hood and Little Red Stocking: On Fairy Tale Jokes]. In E. KALMRE; E.-H. Västrik (eds.): Kes kõlbab, seda kõneldakse. Pühendusteos Mall Hiiemäele [Who is worth it, will be talked about. Dedicated to Mall Hiiemäe]. Tartu: EKM Teaduskirjastus, p. II5-42.

- (2OI2): "Wolf: Der singende W.". In Doris Boden; Susanne Friede; Ulrich Marzolph; Christine Shojaei KAWAN (eds.): Enzyklopädie des Märchens. 
Handwörterbuch zur historischen und vergleichenden Erzählforschung. Berlin, New York: Walter de Gruyter \& Co, p. 956-959.

- (2013): "Estonian Folklore Archives". Oral Tradition vol. 28, no. 2 (October 2OI3): 29I-298. <http://journal.oraltradition.org/issues/28ii/jarv> [last access: November 20I6].

JÄRV, Risto; Mari SARV (2OI4): "From regular archives to digital archives". In Christoph SchmitT (ed.): Corpora ethnographica online. Strategies to digitize ethnographical collections and their presentation on the Internet. Rostoher Studien zur Volkskunde und Kulturgeschichte 5. Münster: Vaxmann Verlag GmbH, p. 49-6o.

Kulasalu, Kaisa (20I5): "Estonian Folklore, Cultural History and Literature in a Digital Form: The File Repository and Archival Information System Kivike". Folklore. Electronic Journal of Folklore vol. 60 (2015): I4I. <http://www.folklore. ee/folklore/vol6o/no4.pdf > [last access: November 20I6].

KÕIVA, Mare; Liisa VESIK (2004): “LEPP: The Database and Portal of South Estonian Folklore”. Folklore. Electronic Journal of Folklore vol. 27 (2004): I33-I62. <http:// www.folklore.ee/folklore/vol27/koivavesik.pdf> [last access: November 20I6].

KõIVA, Mare (2006). "Kuidas kaitsta haldjarahvast. Digiteerimine, andmebaasid ja avatud juurdepääs folklooriarhiivile" [How to protect the Fairy People. Digitisation, databases and open access to folklore archives] In Mare KõIVA (ed.): Võim ja Kultuur 2 [Power and Culture 2]. Tartu: Eesti Kirjandusmuuseum, p 45-83.

LOORITS, Oskar (I936): "Estonian Folklore of Today". Acta Ethnologica I (I936): 34-52.

MEDER, Theo (2OIO): "From a Dutch Folktale Database towards an International Folktale Database". Fabula. Zeitschrift für Erzählforschung. Journal of Folktale Studies vol. 5I (I/2): 6-22.

Meder, Theo; Folgert KArsdorp; Dong Nguyen; Mariët Theune; Dolf Trieschnigg; Iwe Everhardus Christiaan Muiser (20I6): "Automatic Enrichment and Classification of Folktales in the Dutch Folktale Database". The Journal of American Folklore vol. I29, no. 5II (Winter 20I6): 78-96.

OrIOL, Carme (20I5): "Digital Archives and the Study of Catalan Folk Literature". Folklore vol I26, no. 3 (December 20I5): 336-346.

RemMel, Mari-Ann (2004): Arad veed ja salateed. Järvamaa kohapärimus. [Timid waters and secret ways. Place-lore of Järva County]. Tartu: Eesti Kirjandusmuuseum.

- (20II): Päritud paigad. Kohajutte ja legende Rae vallast. [Inherited places. Local tales and legends from Rae municipality]. Jüri, Tartu: [Rae vallavalitsus, Eesti Kirjandusmuuseum].

- (20I4): "Kohapärimuse mõiste, uurimislugu ja tunnusjooned". [The Concept and Research History of Place Lore]. In Heiki VALK (ed.): Muistis, koht ja pärimus II. Pärimus ja paigad. [Monument, site and oral lore II. Lore and places]. Muinasaja Teadus 26: 2. Tartu: Tartu Ülikool, p. I3-70. 
VALPER, Valdo (20IO): Metsast leitud kirik. Mõtsast löütü kerik. Urvaste kohapärimus. [The Church Found in the Wood. Local lore of the Urvaste parish]. Tartu: EKM Teaduskirjastus.

VK XI = Kodavere regilaulud . [Folk songs from Kodavere parish]. Liina SAARLO; Edna TUVI (comp.), Janika OrAS; Kristi SAlve (eds.): Vana Kannel XI. [Old Harp XI]. Monumenta Estoniae antiquae [I]. Tartu: [EKM Teaduskirjastus] 2014.

VoolaID, Piret (2003): “Constructing Digital Databases of the Periphery of Estonian Riddles. Database Estonian Droodles". Folklore. Electronic Journal of Folklore vol. 25: 87-92. <http://www.folklore.ee/folklore/vol25/droodles.pdf> [last access: November 20I6].

VÄSTRIK, Ergo-Hart (2OIO): “Archiving Tradition in a Changing Political Order: From Nationalism to Pan-Finno-Ugrianism in the Estonian Folklore Archives". In Culture Archives and the State: Between Nationalism, Socialism, and the Global Market. (Working Papers of the Center for Folklore Studies, v. I). The Ohio State University: The Center for Folklore Studies. <http://hdl.handle. net/I8II/46903> [last access: November 20I6].

Wolf-KNUTS, Ulrika (200I): "Cultural Conditions for Fieldwork and Archiving". In Ulrika Wolf-KNUTS et alii (ed.): Input \& Output: The Process of Fieldwork, Archiving and Research in Folklore. NNF Publications vol. Io. Turku: Nordic Netvork of Folklore, p. 9-24. 